\title{
PENDAMPINGAN PENYUSUNAN SOAL BERORIENTASI HOTS BAGI PARA GURU SMA
}

\author{
Sebastianus Menggo*1, Leonardus Par $^{2}$, Tabias Gunas ${ }^{3}$, Stanislaus Guna ${ }^{4}$ \\ ${ }^{1,2,3,4}$ Program Studi Bahasa Inggris, Universitas Katolik Indonesia Santu Paulus Ruteng \\ e-mail: sebastian.pradan@gmail.com¹, parma101011@yahoo.com², tobgun74@gmail.com³, \\ stanislausguna@gmail.com ${ }^{4}$
}

\begin{abstract}
Abstrak
Salah satu titik fokus dari pendidikan saat ini adalah penilaian berorientasi pada keterampilan berpikir tingkat tinggi. Keterampilan tersebut mendorong peserta didik mampu berpikir kritis, analitis, sistematis, terutama dalam konteks pemecahan masalah, berkomunikasi, dan berkolaborasi dengan teman sebaya. Namun demikian, belum semua pendidik mampu menyusun soal yang berorientasi pada keterampilan yang dimaksud. Tujuan dari kegiatan pengabdian ini adalah untuk memberikan pengetahuan terkait penyusunan soal yang berorientasi pada keterampilan berpikir tingkat tinggi kepada para guru SMA yang berjumlah 45 orang. Metode yang digunakan untuk mencapai tujuan tersebut adalah ceramah, tanya jawab, diskusi, dan presentasi. Hasilnya menunjukkan, para peserta pelatihan memahami hakikat penyusunan soal yang berorientasi pada Higher Order Thinking Skill (HOTS) dalam pembelajaran. Dari empat pertemuan yang telah dijalankan, para peserta pelatihan mampu mengklasifikasi dan menyusun soal yang berorientasi pada Lower Order Thinking Skill (LOTS), Medium Order Thinking Skill (MOTS), dan Higher Order Thinking Skill (HOTS).
\end{abstract}

Kata kunci: klasifikasi, pelatihan guru, penyusunan soal HOTS

\begin{abstract}
One of the focuses of education today is assessment oriented to the higher-order thinking skills. This skill encourages students could be able to think critically, analytically, systematically, particularly in the context of problem-solving, communicating, and collaborating with peers. However, not all educators have been able to construct the items test based on the skill needed. The purpose of this community service is to provide the knowledge related to the construction of item tests that oriented to the higher-order thinking skills of 45 Senior High School teachers. The methods used to achieve this objective were lecture, question answer, discussion, and presentation. The result showed, the trainees understood the nature of the tests construction oriented to the higher-order thinking skill in learning process. From the four meetings done, the trainees could be able to classify and construct the tests oriented to the lower-order thinking skill, medium-order thinking skill, and higher-order thinking skill.
\end{abstract}

Keywords : classification, HOTS construction tests, teacher training 


\section{PENDAHULUAN}

Asesmen merupakan salah satu komponen penting dalam suatu proses pembelajaran. Jenis asesmen yang diberikan harus sesuai dengan karateristik mata pelajaran dan capaian pembelajaran dari setiap target keterampilan yang hendak dicapai. Pendidik dituntut untuk mampu menerapkan jenis asesmen yang benar, tepat, dan berterima dalam mendukung keberhasilan belajar para peserta didik. Pendidik memberikan asesmen untuk merefleksikan kekurangan dalam pembelajarannya dan menilai pencapaian belajar setiap peserta didik (Anderson, 2003: 24; Suastra \& Menggo, 2020). Di samping itu, asemen diberikan untuk mengetahui efektifitas atas kurikulum, materi ajar, dan strategi pembelajaran yang telah diterapkan, umpan balik kemajuan belajar peserta didik, serta mengetahui pencapaian target pembelajaran (Nitko, 2001: 3-4). Konsep ini sejalan dengan tugas utama seorang pendidik, yaitu, mendidik, mengajar, membimbing, mengarahkan, melatih, menilai, dan mengevaluasi kemajuan belajar peserta didik pada pendidikan anak usia dini jalur pendidikan formal, pendidikan dasar, dan pendidikan menengah (UU No.14 Tahun 2005).

UU di atas mendorong guru untuk menampilkan pendidik yang kompeten, profesional, dan berkepribadian. Sejalan dengan UU yang dimaksud, Peraturan $\begin{array}{lll}\text { Pemerintah No.16 Tahun } 2007 & \end{array}$ menegaskan, empat kompetensi yang melekat pada profesi pendidik, yaitu kompetensi pedagogik, kepribadian, sosial, dan kompetensi profesional. Kompetensi profesional menekankan pada penguasaan materi pembelajaran secara holistik, termasuk melakukan asesmennya; kompetensi pedagogik, berfokus pada pendidik mampu menerapkan ilmu pedagogik yang sesuai dengan karateristik dan perkembangan peserta didik; kompetensi sosial, yaitu peserta didik didorong menjadi pribadi yang mampu hidup berdampingan dengan sesama, masyarakat di sekitar, serta mampu beradaptasi dengan budaya tertentu; dan kompetensi kepribadian berfokus pada mendidik peserta didik menjadi individu yang jujur, beriman, bertanggung jawab, berbudi pekerti luhur, dan berakhlak mulia.

Keempat kompetensi tersebut merupakan faktor kunci tingginya kualitas pembelajaran yang bermuara pada pencapaian keunggulan nilai-nilai akademik dan pembentukan karakter peserta didik (Hindun et al., 2020; Juniantari, Dewi, \& Devi, 2017).

Bahwasanya, berpikir kritis dan mengatasi masalah merupakan salah satu keterampilan yang harus dikuasai oleh peserta didik pada pendidikan abad ke-21. Pendidik mengerahkan empat kompetensi yang ada pada dirinya untuk mendesain kegiatan-kegiatan pembelajaran yang menantang peserta didik untuk mampu berpikir kritis, sistematis, terutama dalam konteks pemecahan masalah, berkomunikasi, dan berkolaborasi dengan teman sebaya dan berbagai pihak, sehingga mereka mampu menghadapi persaingan global yang makin kompleks (Menggo, 2020). Keterampilan berpikir kritis memampukan peserta didik untuk menggunakan sistem berpikir yang kompleks dalam berinteraksi, membuat keputusan yang tepat, serta mampu mengatasi sejumlah masalah dalam proses pembelajaran (Tjahyanti, Adiarta, \& Gitakarma, 2019). 
Higher Order Thinking Skill (HOTS) adalah kemampuan berpikir tingkat tinggi yang berada pada tingkat kemampuan berpikir analisis, evaluatif, dan menciptakan (C4-C6 dalam taksonomi Bloom) (Ahmad, 2019). Penyusunan soal-soal dalam setiap mata pelajaran tetap mempertimbangkan komposisi yang proporsional antara kemampuan berpikir tingkat rendah (lower order thinking skill), yaitu mengingat dan memahami (C1 dan C2), dan kemampuan berpikir tingkat sedang (medium order thinking skill), yaitu mengaplikasikan (C3) (Ahmad, 2018). Soal-soal yang berorientasi pada HOTS merupakan porsi yang lebih banyak dalam implementasi kurikulum 2013 yang diterapkan di sekolah formal mulai tingkat dasar, menengah maupun perguruan tinggi (Pamungkas, 2018).

Studi pendahuluan (preliminary study) berupa Focus Group Discussion (FGD) dan kuesioner yang dilakukan oleh Menggo, Par, Gunas, dan Guna (2020) dengan para guru SMA Swasta Pancasila Borong, di kecamatan Borong, kabupaten Manggarai Timur, NTT, diperoleh bahwa 1) $88 \%$ para guru belum sepenuhnya memahami penyusunan soal-soal yang berorientasi pada kemampuan berpikir tingkat tinggi (higher order thinking skill); 2) 82\% kurang memahami klasifikasi penyusunan soal-soal yang berbasis pada HOTS, MOTS, dan LOTS; 3) 86\% kurang memahami penilaian portofolio sebagai asesmen yang ditekankan dalam pembelajaran dewasa ini; dan 4) $92 \%$ menginginkan adanya sharing konsep merdeka belajar, sekolah merdeka dalam mendorong semangat belajar peserta didik. Hasil studi awal ini perlu ditindaklanjuti dengan suatu pelatihan yang lebih komprehensif dan mendalam sehingga berkontribusi nyata terhadap kebutuhan dan persoalan yang dihadapi para Guru.

Data pada studi pendahuluan di atas juga, memiliki peran penting dalam mendukung keberhasilan suatu kegiatan pelatihan. Menggo, Suastra, Budiarsa, dan Padmadewi (2019) mengklaim bahwa analisis kebutuhan mempunyai peran strategis, yaitu menyediakan data untuk membantu para guru dalam mengambil suatu keputusan yang tepat untuk mengembangkan materi ajarnya. Esensi dari analisis kebutuhan ini juga diperkuat oleh hasil penelitian dari Andi dan Arafah (2017), yang melaporkan bahwa analisis kebutuhan memiliki peran vital dalam suatu proses pembelajaran. Andi dan Arafah menambahkan bahwa data pada analisis kebutuhan dapat menuntun guru untuk merefleksi standar evaluasi hasil belajar serta mengetahui keinginan, keperluan, dan kebutuhan nyata para peserta didik. Di samping itu, hasil analisis tersebut dipahami sebagai ruang refleksi bagi guru untuk menemukan faktor-faktor yang menghambat ketercapaian hasil belajar siswa dan meningkatkan motivasi belajarnya (Menggo, Suparwa, \& Astawa, 2019).

Berdasarkan data dan kebutuhan di atas, maka dipandang perlu melakukan suatu pelatihan bagi para guru. Pelatihan ini dirancang lebih komprehnsif dan mendalam sbagai jalan keluar tentang penyusunan soal-soal berorientasi pada HOTS yang dapat memenuhi target kebutuhan pembelajaran para guru dan peserta didik.

\section{METODE}

Kegiatan Pengabdian ini dilaksanakan pada tanggal 15-17 Februari 2020, di SMA Swasta Pancasila Borong, kecamatan 
Borong, kabupaten Manggarai Timur dengan pesertanya adalah para guru SMA Swasta Pancasila Borong yang berjumlah 45 orang. Sejumlah metode dapat diterapkan dalam suatu kegiatan pelatihan pengabdian kepada masyarakat (Hidayat \& Nurasyiah, 2017; Kurniawan et al., 2017; Ndiung et al., 2020), seperti practice method, discussion, question-answer, on the job, demonstration and example, presentation, simulation, lecture, conference, case study, role play, dan seminar method. Dalam konteks kegiatan pengabdian kepada masyarakat ini, metode pelatihan yang telah diterapkan adalah ceramah, tanya jawab, diskusi, dan presentasi. Keempat metode tersebut dapat dijelaskan sebagai berikut.

1) Ceramah, yaitu kegiatan pelatihan diawali dengan ceramah yang diberikan oleh keempat dosen Prodi pendidikan bahasa Inggris, Universitas Katolik Indonesia Santu Paulus Ruteng. Metode ini berfokus pada penyegaran kembali pengetahuan para guru terkait klasifikasi the Bloom's taxonomy in learning assessment (C1-C6) (Anderson \& Krathwohl, 2001: 67). Enam tingkatan taksonomi Bloom ini, dibagi dalam tiga bagian, yaitu C1 dan C2 sebagai Lower Order Thinking Skill (LOTS), C3 sebagai Medium Order Thinking Skill (MOTS), dan C4-C6 sebagai Higher Order Thinking Skill (HOTS). Pada metode ini juga, keempat dosen dibantu oleh lima orang mahasiswa tingkat akhir dari prodi yang sama. Mahasiswa berperan sebagai pembawa acara, moderator, notulen, dokumentasi kegiatan, dan memperlancar semua kegiatan pada saat pelatihan berlangsung.

2) Tanya jawab, yaitu metode yang diterapkan setelah metode ceramah.
Para guru diberi kesempatan untuk bertanya dan langsung dijawab oleh para pelatih (empat dosen) terkait penyusunan soal-soal yang sesuai dengan klasifikasi taksonomi Bloom, yaitu LOTS, MOTS, dan HOTS.

3) Diskusi, yaitu metode yang menuntut peserta pelatihan didorong untuk memberikan usul-saran dan pendapat terkait materi pelatihan. Para guru diberi kesempatan seluas-luasnya untuk sharing pengalaman nyata mereka dalam menyusun soal-soal sesuai dengan mata pelajaran yang diampunya dan sejumlah kendala yang ditemukan di lapangan. Keempat dosen memberikan peserta yang lain untuk menanggapinya. Segala input diterima oleh keempat dosen dan penyusunan soal-soal berorientasi pada HOTS berjalan lancar dan sukses.

4) Presentasi, yaitu metode yang berfokus pada peragaan dan penjelasan bagaimana cara-cara melakukan suatu pekerjaan melalui contoh atau percobaan yang didemontarsikan atau dipresentasikan. Keempat dosen menjelaskan hakikat HOTS dan contoh konstruksi soalnya dalam interaksi pelajaran sehari-hari yang diampu masing-masing guru mata pelajaran. Contoh-contoh soal yang berorientasi HOTS, MOTS, dan LOTS diberikan oleh para narasumber pada mata pelajaran bahasa Inggris, baik yang diambil dari soal-soal UN, soal-soal MID dan UAS yang telah dibuat guru, maupun soal dalam konteks interaksi pembelajaran sehari-hari. HOTS dalam pembelajaran rutinitas, misalnya: Students are asked to compose a letter of invitation of birthday party (C6); Why do you learn English to such an advance level? (C5); In what 
ways and contexts is English important for your future life? (C4). MOTS, misalkan, Can you give me simple sentence of applying simple present tense? (C3). LOTS, yaitu: Do you understand the classification of English word classes? (C2) dan do you know the use of simple present tense? (C1). Selain itu, para narasumber juga memberikan contoh-contoh soal UN bahasa Inggris yang berorientasi pada HOTS. Misalnya, what does second paragraph discuss about? (C4); Why does second speaker suggest her friend to go home? (C5), dan masih banyak lagi. Setelah itu, para guru memahami, mengikuti contoh yang dibuat oleh tim pelatih, lalu para peserta pelatihan mempresentasikan hasil kerjanya di depan tim pelatih, lalui diakhiri dengan evaluasi bersama.

\section{HASIL DAN PEMBAHASAN Workshop}

Workshop diawali dengan perkenalan singkat biodata dari empat orang dosen. Workshop dimoderatori oleh mahasiswa yang mendampingi tim pengabdi di SMA Swasta Pancasila Borong. Kegiatan pengabdian ini bernaung dibawah tema "HOTS in English Classroom". Tema ini disajikan oleh empat narasumber yang berkompeten dengan topik yang relevan dengan tema ini. Topik pertama tentang "penyusunan soal-soal berorientasi pada HOTS" disajikan oleh Dr. Leonardus Par yang merupakan dosen Program Studi Pendidikan Bahasa Inggris, Universitas Katolik Indonesia Santu Paulus Ruteng yang berlatar belakang pendidikan doktor di bidang pendidikan bahasa Inggris. Pemateri pertama ini menjelaskan secara sistematis materi yang menjadi tanggung jawabnya, seperti hakikat HOTS dalam sistem penilaian pembelajaran, mengapa dan apa itu HOTS, klasifikasi taksonomi Bloom (HOTS, MOTS, dan LOTS), dan peran HOTS dalam meningkatkan keterampilan berpikir kritis para perserta didik.

Pemaparan pemateri pertama ini sejalan dengan penilaian yang menekankan pada kemampuan berpikir tingkat tinggi (higher order thinking skill), yaitu target penilaian yang berorientasi pada ketercapaian berpikir kritis, kreatif, inovatif, serta mampu memecahkan sejumlah masalah yang lebih kompleks dengan tepat dan benar (Ndiung \& Jediut, 2020; Poerwanti \& Tribudhiart, 2020).

Pemateri kedua adalah Dr. Sebastianus, M.Pd yang berlatar belakang pendidikan doktor di bidang ilmu Linguistik, memaparkan dan menyajikan topik "inovasi dan kreativitas pembelajaran". Pamateri kedua ini menekankan pada alokasi waktu dan peran peserta didik dalam pembelajaran. Menurutnya, sediakan waktu yang seluas-luasnya kepada peserta didik untuk mereka berinovasi dan berkreasi. Guru menjalankan perannya sebagai fasilitator dan stimulator dalam pembelajaran. Berikan apresiasi yang sepantasnya terhadap hasil kreativitas peserta didik dalam menyelesaikan sejumlah tugas yang diberikan. Inovasi merupakan cikal bakal dari kreativitas dan itu bisa terwujud ketika guru memberikan alokasi waktu yang cukup dan pendampingan yang prima terhadap peserta didik.

Pemateri ketiga adalah Tobias Gunas, M.Pd, seorang magister dalam bidang pendidikan bahasa Inggris menyajikan materi tentang "HOTS dalam penilaian portofolio dan penilaian berbasis proyek dalam pembelajaran". Menurut pemateri yang ketiga ini, guru didorong untuk mampu menerapakan konsep HOTS dalam sejumlah jenis penilaian. Dia menambahkan bahwa guru harus mampu membedakan antara penilaian portofolio, autentik, performansi, dan penilaian proyek 
dengan penilaian berbasis pada tugas-tugas harian dari setiap mata pelajaran yang diajarkan oleh guru. Penilaian dari hasil pekerjaan rumah siswa tidak sama dengan penilaian berbasis proyek. Guru juga didorong untuk bisa bekerja lebih ekstra untuk mengumpulkan, menilai, mengomentari sejumlah portofolio dari setiap peserta didik. Dengan portofolio tersebut, guru dapat menilai kekurangan dan kemajuan belajar setiap peserta didik serta level kemampuannya pada tingkat LOTS, MOTS atau HOTS.

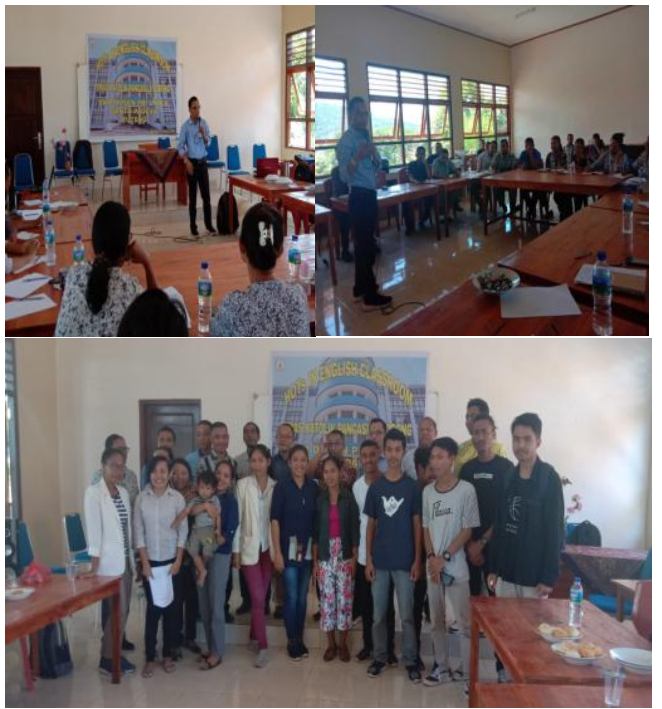

Gambar 1. Pelatihan Bersama Narasumber

Pemateri keempat adalah Stanislaus Guna, M.Pd, seorang magister dalam bidang pendidikan bahasa Inggris menyajikan materi tentang "strategi guru dalam meningkatkan motivasi belajar". Pemateri yang keempat ini berfokus pada esensi dari motivasi dalam keberhasilan belajar siswa. Motivasi menurutnya adalah variabel moderator yang berkontribusi signifikan dalam ketercapaian target belajar peserta didik. Hal ini sejalan dengan yang ditegaskan oleh Rismiyenti (2018), yang mengatakan bahwa motivasi berperan penting dalam mempercepat ketercapaian belajar peserta didik. Motivasi sebagai mesin penggerak utama bagi siswa dalam memenuhi learning outcomes yang maksimal (Menggo, 2018). Menggo menambahkan bahwa semakin tinggi motivasi yang dimiliki, semakin besar nilai juang seseorang untuk menggapai target pembelajarannya.

\section{Penyusunan dan presentasi hasil kegiatan}

Kegiatan pengabdian pada penyusunan soal-soal berbasis pada HOTS dilakukan secara individu dan kelompok sesuai dengan mata pelajarannya masingmasing. Para peserta dibagi dalam rumpun mata pelajaran, setelah mereka memahami hakikat HOTS dalam sistem penilaian yang telah dijelaskan oleh para narasumber. Para narasumber mendampingi secara bergilir pada setiap kelompok dalam melakukan diskusi internal kelompok. Pendekatan dan bahasa yang berbasis budaya digunakan dalam pendampingan setiap kelompok tersebut. Dengan diskusi berbasis budaya, para peserta pelatihan merasa senang dan antusias untuk membagi tantangan yang mereka hadapi dalam menyusun soal-soal yang berorientasi pada HOTS. Pendekatan sosiokultural dapat digunakan dalam diskusi ilmiah. Pendekatan tersebut dapat mendorong peserta diskusi untuk terlibat secara aktif selama kegiatan berlangsung (Menggo, 2017). Menggo menambahkan bahwa diskusi yang berbasis pada budaya setempat memengaruhi psikologi peserta diskusi untuk menyampaikan pendapatnya secara terbuka dan jujur. Setiap peserta terlibat aktif dalam penyusunan soal-soal dan hasilnya ditelaah bersama dalam kelompok, lalu dipresentasikan depan para narasumber dan kelompok mata pelajaran lainnya. Dalam mempresentasikan hasil 
kerja dalam kelompok tersebut, kelompok lain aktif bertanya dan memberikan masukan yang relevan atas soal-soal yang telah disusun oleh kelompok. Kelompok yang mempresentasikan hasil kerjanya menanggapi dengan cermat atas berbagai bentuk pertanyaan dan masukan yang diberikan oleh kelompok lain. Selama proses diskusi antar kelompok berlangsung, para narasumber mendengar dan mencatat masukan dan pertanyaan dari peserta diskusi. Di samping itu, para mahasiswa juga aktif dalam sesidiskusi ini. Mereka bergabung dengan kelompok diskusi para guru. Ketika kelompok menemukan jalan buntu atas pertanyaan dan masukan, mereka memberikan kesempatan kepada para narasumber untuk menanggapinya. Pendampingan masing-masing kelompok berjalan dengan baik dan lancar yang ditandai oleh banyaknya peserta yang bertanya dan kelompok lain memberikan respon, lalu diakhiri dengan input dari para pemateri untuk masingmasing kelompok. Selanjutnya, para peserta pelatihan menyetujui bahwa pelatihan penyusunan soal-soal berorientasi HOTS dijadikan workshop rutin untuk mendukung keberhasilan mereka dalam menyusun soalsoal HOTS serta penyegaran pengetahuan tentang inovasi pembelajaran. Para peserta pelatihan juga memohon pengertian dan kesedian para narasumber untuk mendampingi mereka dalam penyusunan soal-soal HOTS tahap selanjutnya. Tabel 1 dibawah ini merupakan hasil sejumlah cuplikan sesi tanya jawab peserta dengan para pemateri pada saat kegiatan pelatihan berlangsung. Setelah melakukan workshop tentang penyusunan soal-soal berorientasi pada HOTS, inovasi dan kreativitas pembelajaran, dan strategi guru dalam meningkatkan motivasi belajar, peserta pelatihan memahami sejumlah persoalan yang mereka hadapi, seperti yang dideskripsikan pada pada Tabel 1 di atas. Esensi pelatihan sangat bermanfaat bagi peserta pelatihan. Konsep ini sejalan dengan apa yang diungkapkan oleh Yuniarti dan Lingga (2019). Mereka menegaskan bahwa Pelatihan berpengaruh terhadap kinerja para guru. Guru-guru menurut mereka, semakin termotivasi untuk melaksanakan tugasnya dan lebih memahami proses dalam mendidik, mengarahkan, dan mengevaluasi capaian pembelajaran peserta didik. Dengan pelatihan para guru memperoleh, meningkatkan, serta mengembangkan kompetensi yang dimilikinya. Begitupun yang dilaporkan oleh Rusdin (2017) dan Emaliana, Rahmiati, Suwarso, dan Inayati (2019). Mereka memaparkan bahwa pelatihan dapat meningkatkan kompetensi para guru, kecakapan, dan keterampilan, dalam menjalankan profesinya.

\section{Evaluasi}

Evaluasi sebagai langkah akhir dari kegiatan pelatihan ini. Evaluasi dibuat dalam bentuk lembar kuesioner. Tujuan utamanya adalah untuk merefleksikan kekurangan, kelemahan, dan keunggulan pelaksanaan pelatihan. Evaluasi berperan penting terhadap keberlanjutan kegiatan pelatihan. Hal ini sejalan dengan apa yang disampaikan oleh Muryadi (2017), yang mengatakan bahwa kegiatan suatu pelatihan tak dapat dihindari dari evaluasi. Evaluasi bertujuan untuk mengetahui apa yang telah dicapai, apa yang belum dicapai berdasarkan standar yang telah ditetapkan. Widyastuti dan Es (2015) juga menegaskan bahwa evaluasi memiliki peran vital dalam suatu pelatihan, yaitu untuk mengetahui keefektifan pelatihan yang telah dijalankan. Widyastuti dan Es menambahkan bahwa evaluasi suatu pelatihan merupakan bagian 
yang tidak dapat dipisahkan dari pelatihan itu sendiri dan evaluasi tersebut merupakan kegiatan yang harus dilakukan untuk mengetahui apakah pelatihan secara keseluruhan berlangsung secara efektif atau tidak.

Dari pelatihan yang telah dijalankan, para peserta mampu menyusun soal-soal yang berorientasi pada HOTS dalam pembelajaran. Setiap kelompok mata pelajaran mempresentasikan hasil kerjanya di depan peserta pelatihan dan narasumber.

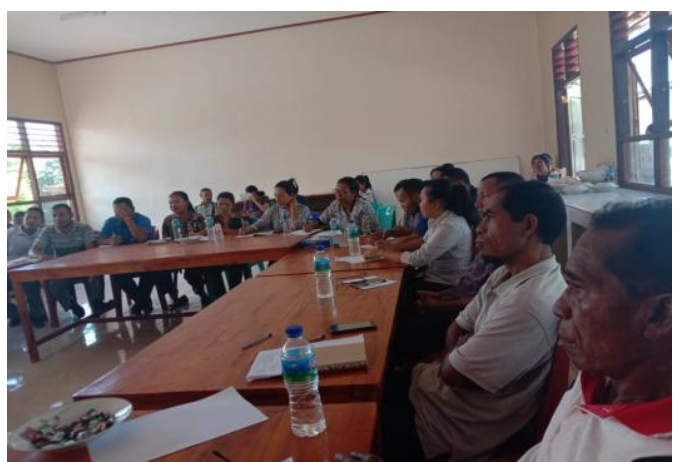

Gambar 2. Evaluasi bersama para guru dan tim pengabdian

Hasil evaluasi bersama pada bagian akhir kegiatan ini menunjukkan bahwa pelatihan ini mendorong para guru memahami konstruksi soal-soal berorientasi pada HOTS, sesuai dengan mata pelajarannya masing-masing. Di samping itu, para peserta pelatihan merasa senang dan puas dengan materi yang disajikan oleh keempat narasumber. Para peserta pelatihan menuturkan bahwa sebelum ada kegiatan ini, mereka hanya mengkonstruksi soal-soal yang merujuk pada buku-buku wajib setiap mata pelajaran. Pelatihan ini membuka wawasan mereka terkait proporsional penyusunan soal sesuai dengan taksonomi Bloom, yaitu soal-soal yang berorientasi pada keterampilan berpikir tingkat rendah (C1 dan C2), berpikir tingkat sedang (C3), dan berpikir tingkat tinggi (C4-C6).

Peran Perguruan Tinggi untuk mendampingi sekolah yang membutuhkan pemecahan masalah terkait konstruksi soalsoal yang berorientasi pada HOTS berjalan sesuai perencanaan. Sejumlah usul-saran terkait hal-hal teknis didapatkan dalam pelatihan ini. Secara keseluruhan hasil dari tahapan evaluasi menunjukkan respon positif akan kebermanfaatan pelatihan konstruksi soal-soal HOTS dalam meningkatkan kompetensi guru. Kepala sekolah yang mewakili SMA Swasta Pancasila Borong, memberi kesan yang positif terhadap pelatihan ini. Menurutnya, pelatihan ini sangat bermanfaat bagi para guru terutama terkait dengan konstruksi soal-soal HOTS. Sekolah memberikan apresiasi dan mengharapkan adanya kerjasama sebagai mitra strategis dan saling menguntungkan antara Prodi Pendidikan Bahasa Inggris, Universitas Katolik Indonesia Santu Paulus Ruteng dan pihak sekolah sehingga kegiatan ini dilakukan secara berkesinambungan dalam meningkatkan kompetensi para guru.

Tabel 1. Cuplikan Tanya Jawab Para Peserta Kegiatan

\begin{tabular}{ll}
\hline \multicolumn{1}{c}{ Pertanyaan } & \multicolumn{1}{c}{ Tanggapan Pemateri } \\
\hline Penanya 1: & Pemateri 1: \\
Apakah soal-soal & Pada dasarnya kita semua menghendaki lulusan yang berkualitas \\
berbasis HOTS wajib & agar peserta didik mampu berpikir kritis, literal, dan sistemis, \\
dalam sistem penilaian & terutama dalam pemecahan masalah sehingga mereka bisa \\
\hline
\end{tabular}


dan Apa HOTS berlaku bagi peserta didik kelas rendah? Mohon tanggapan dan penjelasannya.

bersaing dan menjadi pemenang dalam persaingan yang ada. Aktivitas pembelajaran yang berorientasi pada keterampilan berpikir tingkat tinggi merupakan salah satu dari peningkatan kualitas lulusan kita. Sesungguhnya, soal-soal yang berorientasi pada Keterampilan Berpikir Tingkat Tinggi atau Higher Order Thinking Skill (HOTS) memampukan peserta didik berpikir analitis, evaluatif, dan kreatif. Pemerintah melalui Kemendikbud mewajibkan semua guru pada setiap satuan pendidikan formal untuk mendesain pembelajaran dan standar penilaian berorientasi pada HOTS demi peningkatan kualitas Pendidikan di Indonesia. Bapak/ibu guru yang terbiasa dengan penyusunan soal-soal berorientasi pada Keterampilan Berpikir Tingkat Rendah atau Lower Order Thinking Skill (LOTS) dan Keterampilan Berpikir Tingkat Sedang atau Medium Order Thinking Skill (MOTS) untuk segera beradaptasi dengan tuntutan HOTS demi kualitas peserta didik kita.

Penanya 2:

Saya telah

berpengalaman

mengajar kelas 1 dan 2

SMA kurang lebih 14

tahun. Berbagai

persoalan saya hadapi

dan berjalan dengan

baik. Namun, konsep

merdeka belajar yang

dipopulerkan oleh

Menteri Nadiem

disalahartikan oleh

sebagain siswa saya.

Mohon tanggapan dan

komentar bapak

pemateri kedua tentang

konsep merdeka belajar

yang dengan sistem

penilaian berorientasi HOTS.
Pemateri 2:

Pengalaman bapak sudah luar biasa dalam mendidik, mengarahkan, dan menilai keberhasilan belajar peserta didik. Tentu begitu banyak suka dan duka yang bapak alami, dan semua itu bapak jalani dengan penuh tanggungjawab demi masa depan putra-putri kita. Sesungguhnya, merdeka belajar, sekolah merdeka yang dicanangkan oleh menteri Nadiem patut diapresiasi oleh kita semua. Merdeka belajar yang dimaksud oleh beliau adalah berikan waktu yang sebanyak-banyaknya kepada peserta didik untuk berkreasi dalam proses pembelajaran. Berikan kepercayaan untuk memanfaatkan potensi yang ada pada diri mereka. Desaindesain aktivitas pembelajaran yang berbasis student-centered menjadi fokus utama kita, seperti task-based learning, problembased, project-based, cooperative learning, contextual-based, serta menerapkan performance-based assessment. Ketika porsi waktu yang diberikan kepada siswa banyak maka bukan tidak mungkin mereka akan berinovasi dan berkreasi sesuai dengan pemahaman mereka. Kita sebagai pendidik terus mengarahkan kemajuan belajar peserta didik dengan memberikan masukanmasukan yang substansial atas hasil yang mereka telah lakukan. Merdeka belajar, sekolah merdeka adalah siswa menjadi pembelajar mandiri, inovatif, dan kreatif dengan tetap mengikuti kaidah-kaidah yang sesuai dengan tujuan pembelajaran

\section{Pemateri 3:}

Penilaian berbasis proyek sesungguhnya tidak begitu sulit kita terapkan dalam suatu proses pembelajaran. Penilaian proyekpun dapat diterapkan pada semua mata pelajaran yang kita ampu. Penilaian proyek mefasilitasi siswa kita untuk lebih mengenal (C1), mengevalusi, dan menganalsis (C4 dan C5) potensi dirinya dan meningkatkan kompetensi sosialnya karena mereka harus bekerja 
bentuk nyata dan teknik penilaian berbasis proyek berorientasi HOTS yang bisa saya berikan?

sama dengan teman sebayanya dalam menyelesaikan proyek tersebut. Dari situasi ini HOTS yaitu C4 dan C5 sudah terimplementasikan dengan baik. Penilaian berbasis proyek berfokus pada tiga poin penting, seperti 1) manajemen waktu, yaitu siswa didorong untuk mampu memanfaatkan waktu yang diberikan untuk menyelesaikan proyek tersebut dengan tetap mengikuti pedoman dari guru; 2) relevansi, yaitu sesuaikan dengan karateristik mata pelajaran yang kita ampu dengan pengetahuan yang telah dimiliki siswa dan target capaian belajar siswa, 3) orisinalitas, yaitu proyek yang telah diselesaikan oleh siswa merupakan hasil karya mereka sendiri. Guru dapat membandingkan progres akademik siswa dalam kelas dengan hasil karya yang dikerjakan di luar kelas. Dari situasi ini, poin nomor 2 dan 3 dapat dikategorikan dalam HOTS, yaitu revelansi terkait dengan analisis (C4) dan orisinalitas terkait dengan C6, karena siswa didorong untuk menghasilkan karya autentik mereka.

Penanya 4:

Saya selaku guru bahasa Inggris di kelas $X$ dan XI. Dalam proses pembelajaran saya menemukan masalah terkait dengan keterbatasan kosa kata siswa. Sehebat apapun penilaian yang kita terapkan tidak akan berhasil karena masalah ini. Mohon sharing tipsnya, terutama dosen yang berpengalaman dalam mengampu mata kuliah vocabulary.

\section{Pemateri 4}

Saya setuju dengan bapak terkait dengan penguasaan kosa kata adalah kunci dalam belajar bahasa Inggris. Masalah ini hampir terjadi di setiap sekolah di wilayah kita bahkan Negara kita. Sharing pengalaman dari teman-teman kami di Prodi juga menekankan bahwa mahasiswa tidak bisa berpartisipasi aktif pada mata kuliah speaking, writing, dan reading karena keterbatasan penguasaan kosa kata. Pengalaman saya sendiri ketika mengajar bahasa Inggris di SMA, sejumlah langkah telah saya terapkan untuk meningkatkan motivasi belajar dan penguasaan kosa kata para siswa, seperti daily vocabulary report program, describing favorite palce/thing, paraphrasing, dan book review. 15 menit sebelum pelajaran bahasa Inggris dimulai, setiap siswa wajib melaporkan 25 kosa kata baru yang mereka belum ketahui sebelumnya. Dalam kegiatan ini, guru bahasa Inggris hanya memilih 3 siswa secara acak dari keseluruhan siswa. Ketika seorang siswa mempresentasikan 25 kosa kata baru di depan kelas, siswa yang lainnya wajib menjawab sinonim dan antonim dari kata-kata tersebut. Konsisten teknik ini dijalankan selama satu semester, hasilnya sangat menakjubkan. Kosa kata mereka banyak, maka keterampilan-keterampilan lain dalam bahasa Inggris pasti berjalan. Bahasa Inggrisnya bagus, motivasi belajarnya pasti meningkat. Teknik ini bisa diselingi dengan teknik yang lain untuk menghindari kejenuhan belajar siswa.

\section{KESIMPULAN}

Setelah melakukan pelatihan penyusunan soal-soal berorientasi HOTS, maka dapat disimpulkan bahwa para peserta telah memahami penyusunan soalsoal yang berorientasi pada kemampuan berpikir tingkat tinggi (higher order thinking skill); para peserta telah memahami klasifikasi penyusunan soal-soal yang berbasis pada HOTS, MOTS, dan LOTS; dan para peserta mendapat penyegaran 
konsep merdeka belajar, sekolah merdeka dalam mendorong semangat belajar peserta didik.

\section{DAFTAR PUSTAKA}

Ahmad, K. (2018). The Implementation of teaching LOTS and HOTS in English teaching-learning process in Senior High School. Retain, 6(1), 121-128.

Ahmad, I. F. (2019). Analisis higher order thinking skills (HOTS) pada soal ujian akhir siswa kelas 6 KMI dalam kelompok mata pelajaran dirasah Islamiyah di Pondok Modern Tazakka Batang. Jurnal Pendidikan Agama Islam, 16(2), 138-164. https://doi.org/10.14421/jpai.2019 .162-02

Anderson, L. W., \& Krathwohl, D. R. (2001). A taxonomy for learning, teaching, and assessing: $A$ revision of Bloom's taxonomy of educational objectives (A bridged edition). New York: Addison Wesley Longman, Inc.

Anderson, L. W. (2003). Classroom assessment: Enhancing the quality of teacher decision making. New Jersey: Lawrence Erlbaum Associates, Inc.

Andi, K., \& Arafah, B. (2017). Using needs analysis to develop English teaching materials in initial speaking skills for Indonesian. The Turkish Online Journal of Design, Art and Communication, (Special edition),
https://doi.org/10.7456/1070ASE/ 045

Emaliana, I., Rahmiati, I. I., Suwarso, P. N., \& Inayati, D. (2019). Pelatihan penulisan karya ilmiah bagi guru MGMP bahasa Inggris SMA/MA se-Malang Raya. DINAMISIA-Jurnal Pengabdian Kepada Masyarakat, 3(2), 273279.

Hidayat, H., \& Nurasyiah, N. (2017). Pengaruh diklat (pendidikan dan pelatihan) terhadap prestasi kerja karyawan di Bank BPR Rokan Hulu. Jurnal IImiah Cano Ekonomos, 6(1), 71-82.

Hindun, L., Wahyuni, S., Mashuri, M., Nurwidodo, N., Husamah, H., \& Miharja, F. J. (2020). Upaya peningkatan kualitas pembelajaran IPA di MTs muhammadiyah 1 malang. Jurnal Widya Laksana, 9(1), 56-65.

Juniantari, M., Dewi, N. P. S. R., \& Devi, N. L. P. L. (2017). Pelatihan penyusunan instrumen penilaian aktivitas belajar berorientasi pendidikan karakter bagi guru di gugus 1 Kecamatan Marga. Jurnal Widya Laksana, 6(2), 163-171.

Kurniawan, R. Y. et al., (2017). Pemberian pelatihan analisis butir soal bagi guru di kabupaten Jombang; Efektif?. Jurnal Pemberdayaan Masyarakat Madani, 1(2), 179-193. http://doi.org/10.21009/JPMM.001.2. 03

Menggo, S. (2017). Budaya lonto léok dalam kemampuan berbicara bahasa Inggris. The First International Conference on Language, Literature and Teaching. 
Hal. 722-730. ISSN 2549-5607. Surakarta: Universitas Muhammadiyah.

Menggo, S. (2018). English learning motivation and speaking ability. Journal of Psychology and Instruction, 2(2), 64-69.

Menggo, S., Suastra, I. M., Budiarsa, M., dan Padmadewi, N. N. 2019. Needs Analysis of Academic-English Speaking Material in Promoting 21st Century Skills. International Journal of Instruction, 12(2), 739-754. https://doi.org/10.29333/iji.2019.122 $47 a$

Menggo, S., Suparwa, I. N., \& Astawa, I. G. (2019). Hindering factors in the achievement of English communicative competence in tourism academy students. Aksara, 31(1), 137-152. https://doi.org/10.29255/aksara.v31i 1.235.137-152

Menggo, S., Par, L., Gunas, T., \& Guna, S. (2020). Analisis bebutuhan pengembangan konstruksi soalsoal berbasis HOTS (Unpublished paper). Ruteng: Universitas Katolik Indonesia Santu Paulus.

Menggo, S. (2020). Pembelajaran bahasa abad 21. Seminar Nasional, Universitas Katolik Indonesia Santu Paulus Ruteng, Ruteng, 6 Maret 2020.

Muryadi, A. D. (2017). Model evaluasi program dalam penelitian evaluasi. Jurnal IImiah PENJAS, 3(1), 1-16.

Ndiung, S., \& Jediut, M. (2020). Pengembangan instrumen tes hasil belajar matematika peserta didik sekolah dasar berorientasi pada berpikir tingkat tinggi. Premiere Educandum: Jurnal Pendidikan Dasar dan Pembelajaran, 10(1), 94-111. Doi.org/10.25273/pe.v10i1.6274

Ndiung, S., Menggo, S., Jediut, M., Sennen, E., \& Helmon, A. (2020). Pelatihan penyusunan rencana pelaksanaan pembelajaran model 1 lembar versi Menteri Nadiem bagi guru sekolah dasar. Jurnal Pengabdian Pada Masyarakat, 5(4), 963-973. https://doi.org/10.30653/002.202054 .472

Nitko, A. J. (2001). Educational assessment of students (Third edition). New Jersey: Prentice-Hall, Inc.

Pamungkas, N. A. R. (2018). Penerapan higher order thinking skills (HOTS) untuk meningkatkan keterampilan membaca siswa SMA. Tajdidukasi, 8(1), 127-142.

Peraturan Pemerintah No. 16 Tahun 2007 tentang Standar Kompetensi Guru. Tersedia

di www.vervalsp.data.kemdikbud.go.id. Diunduh pada tanggal 17 Mei 2020

Poerwanti, J. I. S., \& Tribudhiart, T. (2020). Pelatihan merancang instrumen asesmen high order thinking skills pada guru-guru sd di kecamatan Laweyan Surakarta. Jurnal Widya Laksana, 9(1), 66-73.

Rismiyenti, R. (2018). Penggunaan media gambar untuk meningkatkan motivasi belajar mata pelajaran seni budaya (tari) murid kelas VII.4 SMPN 21 Pekanbaru. DINAMISIAJurnal Pengabdian Kepada Masyarakat, 2(1), 68-73. 
Rusdin, R. (2017). Pendidikan dan pelatihan sebagai sarana peningkatan kompetensi guru di SMP Negeri 02 Linggang Bigung. Jurnal Administrative Reform, 5(4), 200-212).

Suastra, I. M., \& Menggo, S. (2020). Empowering students' writing skill through performance assessment. International Journal of Language Education, 4(3), 432-441. https://doi.org/10.26858/ijole.v4i3.15 060

Tjahyanti, L. P. A. S., Adiarta, A., \& Gitakarma, M. S. (2019). Peningkatan kemampuan berpikir kritis kreatif siswa teknik komputer dan jaringan SMK Negeri 2 Seririt melalui pelatihan robot bioloid. Jurnal Widya Laksana, 8(1), 79-84.
Undang-Undang Republik Indonesia Nomor 14 Tahun 2005 Tentang Guru dan Dosen. Tersedia www.jdih.kemenkeu.go.id. Diunduh pada tanggal 16 Mei 2020.

Widyastuti, U., \& ES, D. P. (2015). Evaluasi pelatihan (training) level II berdasarkan teori the four levels Kirkpatrick. Jurnal Pendidikan Ekonomi dan Bisnis, 3(2), 119-128. https://doi.org/10.21009/JPEB.003.2 .1

Yuniarti, D., \& Lingga, L. (2019). Pengaruh pelatihan dan pengembangan sumber daya manusia dalam meningkatkan kinerja guru pada SMK Negeri 1 Muntok. Efektor, 6(1), 98

106. http://doi.org/10.29407/e.v6i1.12794 